\title{
Ecological risk assessment of heavy metals in salt-affected soils in the Natura 2000 area (Ciechocinek, north-central Poland)
}

\author{
Agata Bartkowiak $^{1}$ (D) Joanna Lemanowicz ${ }^{2} \cdot$ Piotr Hulisz $^{3}$
}

Received: 2 January 2017 / Accepted: 25 September 2017 / Published online: 30 September 2017

(C) The Author(s) 2017. This article is an open access publication

\begin{abstract}
This paper aimed to evaluate the ecological risk posed by the accumulation of heavy metals in the saltaffected soils of the habitat covered by the EU Natura 2000 program in relation to the activity of soil redox enzymes. The research was carried out in the halophyte reserve in Ciechocinek (north-central Poland) which is a very specific habitat as it undergoes a long-term human impact related to both the operation of the medical spa town and the agricultural use of soils in the adjacent areas. The obtained results showed that the content of $\mathrm{Zn}, \mathrm{Cu}, \mathrm{Pb}$, and $\mathrm{Cd}$ in the studied soils exceeded the Polish standards. Based on the obtained data and statistical analysis, it was found that metals may come from two different sources: emission from household boiler rooms $(\mathrm{Pb}, \mathrm{Cd})$ and corroded brine sewage pipeline $(\mathrm{Zn}$, $\mathrm{Cu}$ ). They are characterized by limited mobility due to alkaline
\end{abstract}

Responsible editor: Philippe Garrigues

Agata Bartkowiak

bartkowiak@utp.edu.pl

Joanna Lemanowicz

j109@interia.pl

Piotr Hulisz

hulisz@umk.pl

1 Department of Soil Science and Soil Protection, Faculty of Agriculture and Biotechnology, UTP University of Science and Technology, 6 Bernardyńska Street, 85-029 Bydgoszcz, Poland

2 Sub-Department of Biochemistry, Faculty of Agriculture and Biotechnology, UTP University of Science and Technology, 6 Bernardyńska Street, 85-029 Bydgoszcz, Poland

3 Department of Soil Science and Landscape Management, Faculty of Earth Sciences, Nicolaus Copernicus University, 1 Lwowska Street, 87-100 Toruń, Poland environment and strong sorption properties of the clay fraction and organic matter. The correlation analysis indicates that the dehydrogenase activities were negatively correlated with soil electrical conductivity $\left(\mathrm{EC}_{1: 5}\right)(r=-0.665, P<0.05)$. Taking into account the protective status of the area, it is difficult to indicate definitely the solution concerning the land management. However, according to the authors, one should pay special attention to a possibility of using halophytes which occur within the reserve for phytoremediation.

Keywords Enzymes · Halophytes · Heavy metals · Natura $2000 \cdot$ Soil salinity

\section{Introduction}

The Natura 2000 conservation area network has been established by the EU to preserve the most important and endangered habitats and species across Europe. Such areas show a very high susceptibility to unfavorable effect of human activity (Macedo-Sousa et al. 2009; Schröder et al. 2010; Tsiafouli et al. 2013). It comes mostly from the high variation in objects of protection and local environmental conditions within respective areas. Therefore, it is necessary to determine the sensitivity of each protected species and natural habitat to possible threats, including, e.g., the development of settlement network, emissions of pollution to the atmosphere, waters, and soils, excessive exploitation of natural resources (including deforestation), and excessive tourism (Pröbstl 2003; Jankowska-Huflejt 2006; Kopeć et al. 2016; Skordas et al. 2015). A negative reaction of the habitat to the effect of those threats can lead to its total degradation, resulting in a loss of the qualities the protection has been established for.

The accumulation of heavy metals in soils, as one of the key threats for Natura 2000 areas, is closely connected with 
intensive urbanization and industrialization. Heavy metals are natural, nondegradable substances and, as such, they are not broken down in the environment (Kabata-Pendias and Pendias 2001). The content of heavy metals in soils can originate from natural pedogeochemical properties, anthropogenic sources, or a mixture of these two sources. The ratios of these fractions vary widely depending on the type of substances and soil, land use, and the nature and extent of external impacts (Krishna and Govil 2007; Shakeri et al. 2009; Hu et al. 2013; Su et al. 2014). Soil contamination with heavy metals is a major problem as it leads to a negative effect on soil characteristics and the limitation of productive and environmental functions (Uzarowicz 2011; Vacca et al. 2012; Paz-Ferreiro et al. 2014; Kennou et al. 2015; Roy and McDonald 2015).The phytoavailability of such elements depends on soil properties, i.e., $\mathrm{pH}$, cation exchange capacity, organic matter content, redox conditions, and salinity level. For example, a high chloride concentration in soil can have an effective role in increasing solubility of cadmium (Norvell et al. 2000; Weggler et al. 2004; Usman et al. 2005).

Monitoring of soils in protected areas under the Natura 2000 network is essential; it requires both comprehensive physicochemical and microbiological research. Soil enzymes are active in metabolism and catalyzed the processes related to matter processing and energy cycling in the soil environment (Orczewska et al. 2012; Siwik-Ziomek and Lemanowicz 2014). Many of them (for example, dehydrogenases, phosphatases, catalase, protease, and urease) have been proposed as indicators for measuring the degree of soil degradation. The sensitivity to small changes depends on a number of factors, e.g., flora (Bielińska and Gruszecki 2010; Lemanowicz and Bartkowiak 2013), soil type (Bartkowiak and Lemanowicz 2014), and soil profile depth (Lemanowicz and Krzyżaniak 2015). The applicable literature shows that mineral xenobiotics at large amounts inhibit the activity of soil enzymes (Lee et al. 2009; Wyszkowska et al. 2013).

However, there is little recognition of the problem of the effect of the accumulation of heavy metals on the enzymatic activity of soils under saline stress. For that reason, the aim of this paper was to evaluate the ecological risk posed by the accumulation of heavy metals in the salt-affected soils of the habitat covered by the EU Natura 2000 program in relation to the activity of soil redox enzymes. The research involved the halophyte reserve in the small Polish town (Ciechocinek; north-central Poland). It was assumed that long-term human impact related to both the operation of the medical spa town and the agricultural land use in the adjacent areas can affect the relationships between enzymatic activity and other soil properties. The research results can be useful for monitoring of the human-transformed habitats, e.g., in terms of developing new protection recommendations.

\section{Materials and methods}

\section{Study area}

"Ciechocinek" halophyte reserve (1.88 ha), established in 1963, is one of the three reserves of halophytes in Poland. It is located in the Vistula river valley, adjacent to the graduation towers of the Ciechocinek medical spa $\left(52^{\circ} 52^{\prime} \mathrm{N}\right.$; $18^{\circ} 46^{\prime} \mathrm{E}$; Fig. 1). Wooden constructions from the nineteenth century, unique in Europe, were built in order to concentrate the brine in the process of salt production. Wooden graduation towers built according to the project of Stanisław Staszic have ca. $2 \mathrm{~km}$ in length and ca. $15 \mathrm{~m}$ in height. Oak balks constitute their base, whereas frames are built of pine wood. The interiors of these buildings are filled with brushwood of blackthorn (Prunus padus L.) (Gugnacka-Fiedor 2011). Those constructions are unique in Europe wooden structures filled up with blackthorn branches used for salt production process. The brine is condensed as a result of exposure to sunlight and wind and then transported by pipeline to the saltwork.

In the past, meadows in the Vistula River valley (including the reserve) were supplied by groundwater in contact with the Zechstein salt rock deposits. As a result of the valley irrigation and drainage, mostly in the 1950s and 1960s, the groundwater level decreased by more than $1 \mathrm{~m}$. This action has contributed to an almost complete disappearance of halophytes (WilkońMichalska 1962, 1970). Today, little areas of salt-affected soils exist only thanks to the supply with saline sewage from the medical spa town (also from the graduation towers), and thus, the communities of halophytes with Salicornia europaea, Aster tripolium, Puccinellia distans and Spergularia salin occur only within the ditch discharging saline waters, being the south-eastern border of the reserve (Warot and Nienartowicz 2001; Fig. 1). The area of the reserve is mowed and partially grazed. In December 2008, due to its unique character of halophytes on inland stands in Europe, the Special Area of Conservation Natura 2000 PLH 040019 Ciechocinek has been created. It also includes the area of halophytes reserve and the area of the neighboring agricultural land which in the 1960s was the area of salt meadows and the graduation tower (Fig. 1). The latter is a stand of halophytes which could again occupy the area of the reserve after introducing new protection rules (revitalization). The studied soils were formed on the alluvial sediments. According to the international soil classification WRB (IUSS Working Group WRB 2015), most of them can be referred to as Fluvic Gleysols (Salic, Sodic).

\section{Sampling and analysis}

The fieldwork was conducted in 2015. A total of 16 sampling sites were located in the meadow (1-7), along the drainage ditch (8-14 and 16), and in the arable field (15). Soil samples were collected from the $0-20-\mathrm{cm}$ depth in each site. 
Fig. 1 Localization of the study area

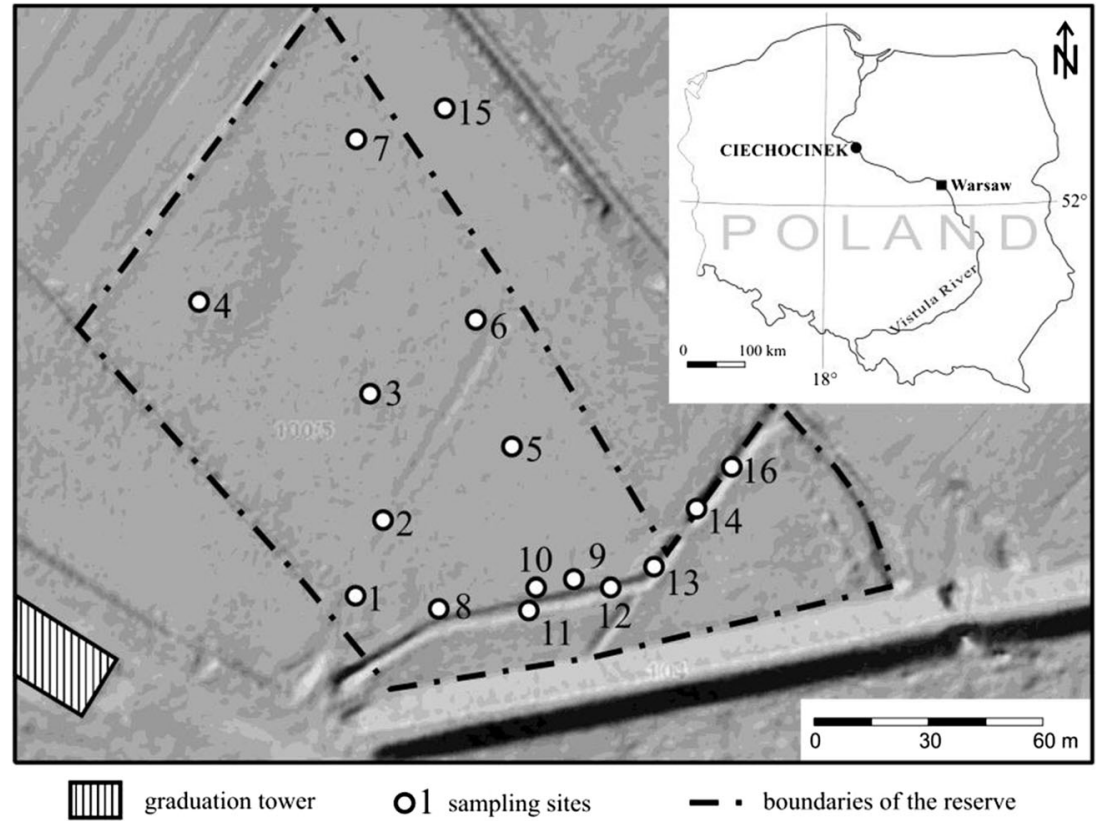

Before analytical processing, soil materials were air-dried at room temperature, disaggregated, homogenized, and sieved through a 2-mm mesh. The following analyses were performed for the soil samples: grain-size distribution by the laser diffraction method applying the Mastersizer MS 2000 analyzer, $\mathrm{pH}$ in $\mathrm{H}_{2} \mathrm{O}$ (PN-ISO 10390: 1997) and $\mathrm{pH}$ in $1 \mathrm{M} \mathrm{KCl}$ potentiometrically (PN-ISO 10390: 1997), the total organic carbon (OC) was determined with the TOC FORMACTSTM analyzer Primacs (provided by Skalar), electrical conductivity of 1:5 soil-water extract $\left(\mathrm{EC}_{1: 5}\right)$ using the conductometric method (van Reeuwijk 2002), and the content of selected heavy metals ( $\mathrm{Pb}, \mathrm{Cu}, \mathrm{Ni}, \mathrm{Cd}$, and $\mathrm{Zn}$ ) by atomic absorption spectrophotometry (AAS) after extraction of samples with a mixture of acids $\mathrm{HF}+\mathrm{HClO}_{4}$ (Crock and Severson 1980).

Sixteen field-moist samples were sieved (2-mm mesh) and stored in a box at $4{ }^{\circ} \mathrm{C}$ for 2 days to stabilize the microbial activity and analyzed for selected redox: dehydrogenase and catalase activity within 1 week (Alef 1995; Alef and Nannipieri 1995). The activity of dehydrogenases (DEH) in soil was determined according to the Thalmann method (1968), after sample incubation with 2,3,5-triphenyl-tetrazolium chloride and a measurement of triphenylformazan (TPF) absorbance at $546 \mathrm{~nm}$, and it was expressed in milligrams of TPF $\mathrm{kg}^{-1} 24 \mathrm{~h}^{-1}$. The activity of catalase (CAT) was assayed with the Johnson and Temple method (1964) with $0.3 \%$ hydrogen peroxide solution as a substrate. The residual $\mathrm{H}_{2} \mathrm{O}_{2}$ was determined using titration with $0.02 \mathrm{M} \mathrm{KMnO}_{4}$ under acidic conditions.

\section{Data analysis}

Due to a considerable influence of anthropogenic transformations, the soils were evaluated using the enrichment factor percentage for heavy metal concentrations according to the following equation (Zonta et al. 1994; Loska and Weichula 2003):

$\% \mathrm{EF}=C-C_{\min } /\left(C_{\max }-C_{\min }\right) \times 100$

where $C$ - mean total concentration in soil, $C_{\min }-$ minimum concentration, and $C_{\max }$-maximum concentration.

The enrichment factor (EF) can give an insight into differentiating an anthropogenic source from a natural origin. Five contamination categories are recognized based on the enrichment factor, where EF $<2$ stands for deficiency to minimal enrichment, EF 2-5-for moderate enrichment, EF 5-20-for significant enrichment, EF 20-40 is very high enrichment, and EF $>40$ is extremely high enrichment (Sutherland 2000).

With the values of the contents of heavy metals recorded in the soils, two geochemical parameters evaluating the anthropogenic effect on the soil environment were calculated.

(i) Contamination factor:

$(\mathrm{CF})-\mathrm{CF}=C / C_{n}$

where $C$ - the mean content of metals from at least 16 sampling sites and $C_{n}$ - geochemical background.

(ii) Contamination degree $\left(C_{\mathrm{deg}}\right)$ of the ecosystem as the sum of $\mathrm{CF}$ for all the metal yields studied.

As a geochemical background, the following values were adopted: $\mathrm{Zn}-19.0 \mathrm{mg} \mathrm{kg}{ }^{-1}, \mathrm{Cu}-4.0 \mathrm{mg} \mathrm{kg}^{-1}, \mathrm{~Pb}-$ $7.1 \mathrm{mg} \mathrm{kg}^{-1}, \mathrm{Ni}-6.5 \mathrm{mg} \mathrm{kg}^{-1}$, and $\mathrm{Cd}-0.13 \mathrm{mg} \mathrm{kg}^{-1}$ (Czarnowska 1996). 
Based on enzymatic activities of the samples, Biological Index of Fertility (BIF) was calculated according to Stefanic et al. (1984):

$\mathrm{BIF}=(1.5 \mathrm{DEH}+100 k \mathrm{CAT}) / 2$,

where $k$ is a factor of proportionality equal to 0.01 .

Basic statistics were used to study tendencies (mean, median) and the variability (standard deviation SD, coefficient of variation $\mathrm{CV}$, minimum and maximum) of the sample population.

The coefficient of variation of the parameters analyzed was calculated as follows:

$\mathrm{CV} \%=(\mathrm{SD} /$ mean $) \times 100$

where $\mathrm{CV}$ - coefficient of variation (\%), SD — standard deviation, mean - arithmetic mean.

The values, where $0-15 \%, 16-35 \%$, and $>36 \%$, indicate low, moderate, or high variability, respectively (Wilding 1985).

This paper presents the arithmetic means of the results from three replications. Besides, the results of the analyses of the features investigated were exposed to the analysis of simple correlation $(p<0.05$ and $p<0.01)$, which determined the degree of dependence between respective parameters. In this study, physicochemical and chemical soil properties $(\mathrm{pH}$, $\mathrm{EC}_{1: 5}$, OC and heavy metals content, and enzymes activities) were analyzed applying the multivariate analyses (cluster analysis CA) with Ward's method (1963). The result of hierarchical cluster analysis has been shown in a form of the dendrogram. Moreover, the principal component analysis (PCA) was used. The first two principal components (PC1 and $\mathrm{PC} 2$ ) were selected to determine which soil properties differentiate respective sampling sites. All the analyses were made using "Statistica 9.0 for Windows Pl" package.

\section{Results and discussion}

\section{Basic soil properties and salinity}

Due to Poland's geographical location, the occurrence of saltaffected soils is conditioned only by the influence of waters with a high mineral content (of natural or anthropogenic origin). This process concerns mostly mineral-organic and organic soils which are characterized by lack of visible salinity features in their morphology. Therefore, the salinization may be considered as secondary to other soil forming processes (Hulisz et al. 2010, 2016).

The results demonstrated a high spatial variability of most basic soil characteristics (Table 1). According to the USDA classification (2006), four textural classes were distinguished: loamy sand (samples 1-3), sandy loam (samples 4, 8, 12, 13, and 16), silty loam (samples 5-7, 9-11, and 14), and loam (sample 15). The content of clay fraction $(<0.002 \mathrm{~mm})$ ranged from 1 to $15 \%(\mathrm{CV}-68 \%)$. The content of the organic carbon (OC) in soil ranged from 13.4 to $124 \mathrm{~g} \mathrm{~kg}^{-1}$. The spatial variation of that element $(\mathrm{CV}-64 \%)$ can be due to the effect of local environmental conditions, namely primary processes of the accumulation of river sediments, long-term exposure of those soils to greater moisture than today (namely before irrigation and drainage in the 1950s and 1960s), sodding, and mud accumulation in the ditch. Electrical conductivity of 1:5 soil-water extract $\left(\mathrm{EC}_{1: 5}\right)$ varied from 1.89 to $14.5 \mathrm{dS} \mathrm{m}^{-1}$ (mean $6.68 \pm 5.06 \mathrm{dS} \mathrm{m}^{-1}$, Table 1). The highest level of salinity was reported for the soils located along the ditch discharging saline sewage from the medical spa town and brine from the graduation tower (samples $8-14$ and 16). According to the formula proposed by Rengasamy (2006), which facilitates converting the $\mathrm{EC}_{1: 5}$ results to saturated extract, half of the soil samples analyzed were classified as strongly saline $\left(\mathrm{EC}_{\mathrm{e}}>16 \mathrm{dS} \mathrm{m}^{-1}\right.$ ) (Jackson 1958). The field studies demonstrated the occurrence of poorly permeable formations (clays) in the subsoils, especially in the area adjacent to the ditch. Therefore, salt migration at greater depth is limited here and evaporation increases soil salinity. On the other hand, the effect of salt aerosols from the graduation tower area on soil properties cannot be excluded. This was particularly evident in less saline soils located further from the ditch area (samples 1-7 and 15). As reported by Czajka et al. (2006), the average concentration of $\mathrm{Cl}^{-}$ions in aerosol around the graduation towers at Ciechocinek is between 0.24 and $9.83 \mathrm{mg} \mathrm{m}^{-3}$.

The ranges of $\mathrm{pH}-\mathrm{H}_{2} \mathrm{O}$ and $\mathrm{pH}-\mathrm{KCl}$ for the soil samples analyzed were 5.4-7.7 and 3.9-7.8, respectively. In general, the $\mathrm{pH}$ values measured in $\mathrm{H}_{2} \mathrm{O}$ for non-saline soils and with a low content of calcium carbonate (also non-limed) are from about 1 to 1.5 units higher than those measured in $\mathrm{KCl}$ (Bednarek et al. 2004). Such dependence was observed only for a few samples (Table 1). In soils containing neutral salts, e.g., $\mathrm{NaCl}$ or limed, the soil reaction is usually neutral or slightly alkaline, and both values can be very similar (Abrol et al. 1988; Piernik et al. 2015). Such properties were recorded for soil samples located along the ditch (samples 8-14 and 16), as well as in arable field (15). A significant relationship between $\mathrm{EC}_{1: 5}$ and $\mathrm{pH}$ values was also confirmed by high values of the correlation coefficient (Table 4).

\section{Heavy metal content and its relation to other soil parameters}

Soil contamination with heavy metals is currently considered as one of the most serious environmental problems due to heavy metal persistence and toxicity, having a great impact as the development of areas without soil in good condition is difficult (Salazar and Pignata 2014). Concentrations of heavy 
Table 1 Basic properties of the studied soils

\begin{tabular}{|c|c|c|c|c|c|c|c|}
\hline \multirow[t]{2}{*}{ Sample no. } & \multicolumn{2}{|l|}{$\mathrm{pH}$} & \multirow[t]{2}{*}{$\mathrm{EC}_{1: 5}\left(\mathrm{dS} \mathrm{m}^{-1}\right)$} & \multirow[t]{2}{*}{$\mathrm{OC}\left(\mathrm{g} \mathrm{kg}^{-1}\right)$} & \multicolumn{3}{|c|}{ Percentage share of fraction } \\
\hline & $\mathrm{H}_{2} \mathrm{O}$ & $\mathrm{KCl}$ & & & Sand* & Silt & Clay \\
\hline 1 & 5.5 & 4.6 & 2.47 & 33.8 & 83 & 16 & 1 \\
\hline 2 & 6.8 & 6.4 & 2.54 & 21.7 & 81 & 18 & 1 \\
\hline 3 & 5.8 & 4.9 & 2.31 & 13.4 & 76 & 22 & 2 \\
\hline 4 & 5.5 & 4.3 & 1.89 & 25.4 & 63 & 34 & 3 \\
\hline 5 & 5.7 & 4.7 & 2.59 & 70.6 & 32 & 60 & 8 \\
\hline 6 & 5.4 & 3.9 & 2.11 & 69.8 & 41 & 51 & 8 \\
\hline 7 & 5.5 & 4.8 & 2.68 & 34.8 & 21 & 66 & 13 \\
\hline 8 & 7.5 & 7.4 & 9.25 & 38.9 & 61 & 34 & 5 \\
\hline 9 & 7.6 & 7.4 & 10.2 & 36.3 & 41 & 53 & 6 \\
\hline 10 & 7.5 & 7.3 & 10.9 & 41.2 & 45 & 50 & 5 \\
\hline 11 & 7.7 & 7.3 & 9.89 & 60.5 & 30 & 55 & 15 \\
\hline 12 & 7.6 & 7.8 & 14.5 & 24.6 & 64 & 33 & 3 \\
\hline 13 & 7.1 & 6.4 & 13.6 & 124 & 52 & 43 & 5 \\
\hline 14 & 7.3 & 7.6 & 4.75 & 19.6 & 17 & 72 & 11 \\
\hline 15 & 7.5 & 7.2 & 2.01 & 29.8 & 52 & 40 & 8 \\
\hline 16 & 7.6 & 7.4 & 15.2 & 40.0 & 48 & 47 & 5 \\
\hline Mean & 6.7 & 6.2 & 6.68 & 42.7 & 50 & 43 & 6 \\
\hline Median & 7.2 & 6.8 & 3.72 & 35.5 & 50 & 45 & 5 \\
\hline Min & 5.4 & 3.9 & 1.89 & 13.4 & 17 & 16 & 1 \\
\hline Max & 7.7 & 7.8 & 14.5 & 124 & 83 & 72 & 15 \\
\hline $\mathrm{SD}$ & 1.0 & 1.4 & 5.06 & 27.4 & 20 & 17 & 4 \\
\hline CV\% & 14 & 23 & 76 & 64.0 & 40 & 38 & 68 \\
\hline
\end{tabular}

*Sand [2.0-0.05 mm], Silt [0.05-0.002 mm], Clay [<0.002 mm] metals in soils can result from natural or anthropogenic factors, with the latter being most common. Metals are usually nondegradable and become toxic if they exceed their threshold level, which poses a threat to biological life. Heavy metals may be bound or sorbed by particular natural substances, which may increase or decrease mobility (Dube et al. 2001). The total content of the analyzed form of heavy metals varied widely: zinc from 23.2 to $420 \mathrm{mg} \mathrm{kg}^{-1}$, copper from 7.48 to $432 \mathrm{mg} \mathrm{kg}^{-1}$, nickel from 0.44 to $21.2 \mathrm{mg} \mathrm{kg}^{-1}$, lead from 10.9 to $531 \mathrm{mg} \mathrm{kg}^{-1}$, and cadmium from 0.00 to $3.49 \mathrm{mg} \mathrm{kg}^{-1}$. A high spatial variability of the results was confirmed by the calculated coefficients (Table 2). The sources and distribution of potentially toxic elements like $\mathrm{Cu}, \mathrm{Ni}, \mathrm{Pb}, \mathrm{Cd}$, and $\mathrm{Cr}$ in the urban environments have been widely studied (Madrid et al. 2002, 2006; Elik 2003). In the town of Ciechocinek, there are many structures, houses, old villas, and guest houses, which are heated in a traditional way. Therefore, a probable source of pollution are dusts from household boiler rooms. As reported by the Provincial Inspectorate of Environmental Protection in Bydgoszcz (http://www.wios.bydgoszcz.pl/), the admissible level of daily average PM10 (particulate matter $<10 \mu \mathrm{m}$; $50 \mu \mathrm{g} \mathrm{m}^{-3}$ ) was exceeded 43 times during 2015 at a limit value of 35 times (Journal of Laws, item 1031, 2012).
The fallout from smokestacks can reach the residential areas depending on the prevailing wind directions. It is known that untreated or unfiltered emissions from most types of combustion and incineration facilities will also carry different trace metals, especially $\mathrm{Cr}, \mathrm{Ni}, \mathrm{Cu}, \mathrm{Zn}$, and $\mathrm{Pb}$ (Govil et al. 2008). Road transport is also a source of air pollution with carbon oxides, hydrocarbons, and lead compounds. According to $\mathrm{Li}$ et al. (2004), the concentration of $\mathrm{Pb}$ in urban soils reflects the significant degree of historical $\mathrm{Pb}$ contamination and the long half-life of $\mathrm{Pb}$ in soils. Low emissions are especially onerous in urban agglomerations and wherever the conditions are unfavorable to the spread of pollution, hence the importance of actions to limit it, e.g., by changing from coal boiler facilities into gas and oil heating. At the same time, the objective is to restrict heating houses with various kinds of waste which often, during the burning process, release considerable amounts of toxic substances. According to the Regulation of the Minister of Environment dated 9 September 2002 on standards for soil quality and land quality standards (Journal of Laws No 165, item 1359, 2002) and dated 1 September 2016 on assessment procedures for the land surface pollution (Journal of Laws item 1395, 2016), it was stated that the admissible contents of $\mathrm{Zn}, \mathrm{Cu}, \mathrm{Pb}$, and $\mathrm{Cd}$ were exceeded in the studied soils (Table 2). High amounts of zinc (94.1- 
Table 2 The content of total zinc, copper, nickel, lead, and cadmium and the activity of dehydrogenases and catalase in the studied soils

\begin{tabular}{|c|c|c|c|c|c|c|c|}
\hline Sites & $\begin{array}{l}\mathrm{Zn} \\
\left(\mathrm{mg} \mathrm{kg}^{-1}\right)\end{array}$ & $\mathrm{Cu}$ & $\mathrm{Ni}$ & $\mathrm{Pb}$ & $\mathrm{Cd}$ & $\begin{array}{l}\text { DEH (mg } \\
\left.\text { TPF kg-1 } 24 \mathrm{~h}^{-1}\right)\end{array}$ & $\begin{array}{l}\mathrm{CAT}\left(\mathrm{mg} \mathrm{H} \mathrm{H}_{2} \mathrm{O}_{2}\right. \\
\left.\mathrm{kg}^{-1} \mathrm{~h}^{-1}\right)\end{array}$ \\
\hline 1 & 23.2 & 7.48 & 1.26 & 31.6 & 0.35 & 0.121 & 0.031 \\
\hline 2 & 32.7 & 7.66 & 1.29 & 32.2 & bdl & 0.632 & 0.121 \\
\hline 3 & 25.0 & 9.33 & 2.09 & 52.2 & bdl & 0.547 & 0.042 \\
\hline 4 & 32.0 & 9.60 & 3.58 & 89.4 & bdl & 0.516 & 0.053 \\
\hline 5 & 87.8 & 29.2 & 21.2 & 531 & 0.16 & 0.558 & 0.064 \\
\hline 6 & 81.5 & 23.3 & 15.4 & 385 & 0.41 & 0.095 & 0.039 \\
\hline 7 & 77.2 & 29.3 & 21.0 & 525 & 0.16 & 0.154 & 0.076 \\
\hline 8 & 94.1 & 225 & 3.88 & 96.9 & 1.25 & 0.119 & 0.087 \\
\hline 9 & 344 & 102 & 1.15 & 28.8 & bdl & 0.096 & 0.032 \\
\hline 10 & 420 & 74.1 & 0.44 & 10.9 & 0.49 & 0.091 & 0.029 \\
\hline 11 & 112 & 16.3 & 17.4 & 436 & 0.30 & 0.106 & 0.026 \\
\hline 12 & 231 & 26.9 & 1.06 & 26.6 & 3.49 & 0.085 & 0.021 \\
\hline 13 & 144 & 432 & 13.2 & 329 & 0.93 & 0.095 & 0.035 \\
\hline 14 & 269 & 59.7 & 0.68 & 16.9 & 0.89 & 0.289 & 0.048 \\
\hline 15 & 82.2 & 76.1 & 18.8 & 470 & 0.90 & 0.781 & 0.298 \\
\hline 16 & 275 & 82.4 & 1.15 & 28.8 & 0.94 & 0.049 & 0.019 \\
\hline Mean & 146 & 75.7 & 7.72 & 193 & 0.64 & 0.271 & 0.063 \\
\hline Median & 90.9 & 29.2 & 2.83 & 70.8 & 0.38 & 0.120 & 0.045 \\
\hline Min & 23.2 & 7.48 & 0.44 & 10.9 & 0.00 & 0.049 & 0.019 \\
\hline Max & 420 & 432 & 21.2 & 531 & 3.49 & 0.781 & 0.298 \\
\hline SD & 124 & 110 & 8.35 & 209 & 0.86 & 0.245 & 0.070 \\
\hline CV\% & 85 & 145 & 108 & 108 & 134 & 91 & 107 \\
\hline
\end{tabular}

$b d l$ below detection limit

$420 \mathrm{mg} \mathrm{kg}^{-1}$ ) and copper (16.3-432 $\mathrm{mg} \mathrm{kg}^{-1}$ ) found in soils sampled along the ditch probably resulted from the corrosion of the brine pipes. It may cause some $\mathrm{Cu}$ and $\mathrm{Zn}$ emissions to the environment, which was confirmed by a significantly positive value of the coefficient of correlation between the content of zinc and electrical conductivity $\left(\mathrm{Zn} \mathrm{EC}_{1: 5} r=0.668, P<0.05\right)$, as well as the content of copper $\left(\mathrm{Cu} \mathrm{EC}_{1: 5} r=0.509, P<0.05\right.$-Table 4). Some physicochemical properties of soils, $\mathrm{pH}$, texture, and organic carbon, are important parameters that control the accumulation and the availability of heavy metals in the soil environment (Dube et al. 2001; Weng et al. 2002; Ashworth and Allowy 2008; Shakeri et al. 2009). Organic matter can be a factor in releasing as well as immobilizing metals in soil. Such dependence can be confirmed by the analysis of correlation as showing significantly positive values of the coefficient of correlation between the content of copper and organic carbon $(r=0.688, P<0.05)$, nickel and organic carbon $(r=0.510, P<0.05)$, and lead and organic carbon $(r=0.510, P<0.05)$ (Table 4$)$. Moreover, the statistically significant relationships between the content of clay fraction and $\mathrm{Pb}$ and $\mathrm{Ni}$ as well as $\mathrm{pH}$ and $\mathrm{Zn}$ and $\mathrm{Cd}$ were found (Table 4).

\section{Degree of anthropogenic soil transformations}

The enrichment factor is used to differentiate trace metals originating from human activities and those of natural sources.
Basically, as the EF value increases, the contribution from non-crustal sources increases. The calculated values of the coefficient of pollution for the surface horizon of the soil in a given area $(\mathrm{EF})$ point to a high pollution with copper (EF$16 \%)$ and cadmium (EF-18\%), whereas zinc, nickel, and lead indicated extreme contamination of surface soil horizons (Fig. 2). Literature reports on (Ali and Malik 2011; Atiemo et al. 2011; Ramachandra and Shwetmala 2009; Thorpe and Harrison 2008; Loska et al. 2004) increased EF values in urban soils are mostly due to industrial and road traffic emissions.

The contamination coefficient (CF) allowed for the classification of the soils to the appropriate group, depending on the geochemical background factor. The contamination factor or anthropogenic factor for each element was computed and the result is presented in Table 3. According to the criterion developed by Håkanson (1980), the soil from sampling sites 9-10, $12-14$, and 16 demonstrated a very high value of the contamination factor of zinc; from sampling sites 5, 7-10, 12-16 with copper; from sampling sites 3-8, 11, 13, and 15 with lead; and from sampling sites $8,12-16$ with cadmium. The sum of contamination factors for all the metals examined indicates a considerable degree of contamination in soil. It is inferred that the contamination comes from the anthropogenic sources. The overall assessment of the soil pollution was tested based on the degree of contamination $\left(C_{\mathrm{deg}}\right)$. According to Håkanson 
Fig. 2 Enrichment factor

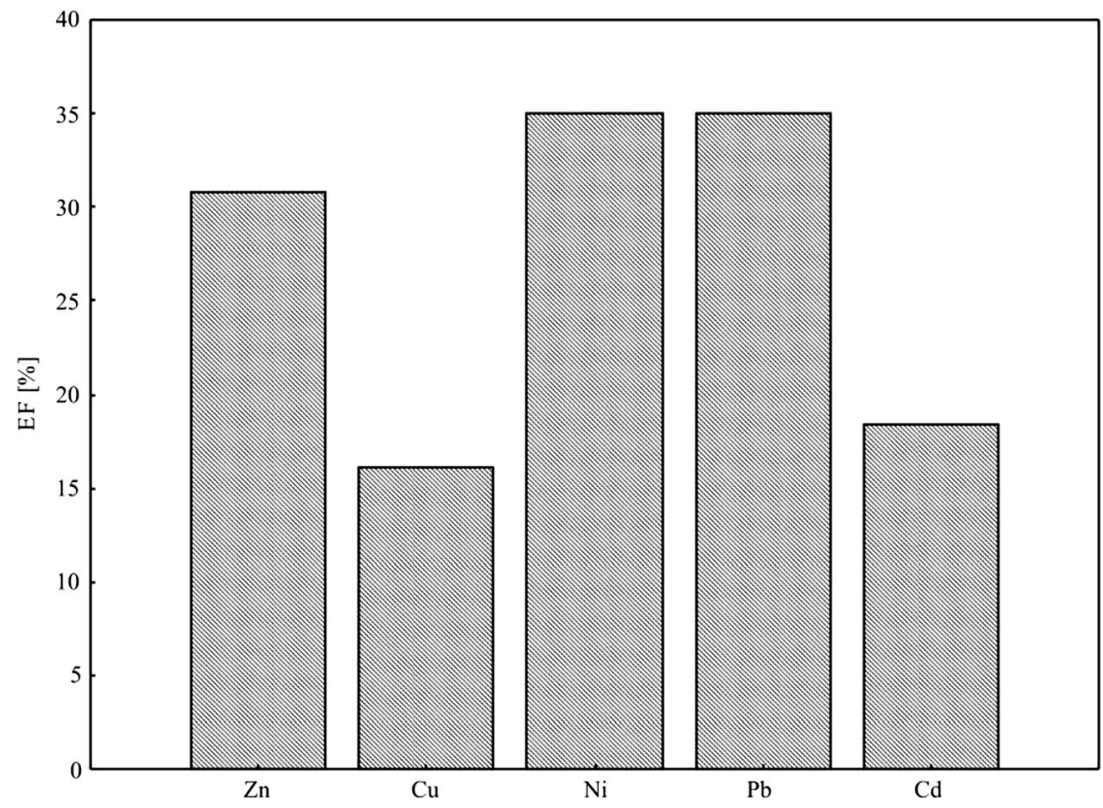

(1980), only for a single sampling site (no. 2) was there identified a low degree of contamination, sampling sites 1,3 , and 4 moderate, and in the others - high and very high (Table 3 ). The degree of contamination in soil samples is considerable and very high; there should be a thorough heavy metal monitoring in soil to prevent relative health hazards to man and livestock in the area (Loska et al. 2004; Bambara et al. 2015).

The enzyme activities (catalase, dehydrogenases) showed fluctuating results in the present study (Table 2). The activities of catalase in soil ranged from 0.019 to $0.298 \mathrm{mg} \mathrm{H}_{2} \mathrm{O}_{2} \mathrm{~kg}^{-1} \mathrm{~h}^{-1}$ (with a mean value of $0.063 \mathrm{mg} \mathrm{H}_{2} \mathrm{O}_{2} \mathrm{~kg}^{-1} \mathrm{~h}^{-1}$ ) and dehydrogenases from 0.049 to $0.781 \mathrm{mg}$ TPF kg $24 \mathrm{~h}^{-1}$ (with a mean value of $0.271 \mathrm{mg}$ TPF kg $24 \mathrm{~h}^{-1}$ ). The highest activity of enzymes in soil was reported from site 15 (agricultural area)CAT $0.298 \mathrm{mg} \mathrm{H}_{2} \mathrm{O}_{2} \mathrm{~kg}^{-1} \mathrm{~h}^{-1}$ and DEH $0.791 \mathrm{mg}$ TPF kg $24 \mathrm{~h}^{-1}$. Dehydrogenase activity showed a significant negative correlation with soil $\mathrm{EC}_{1: 5}(r=-0.665$, $P<0.05)$. Similarly, Batra and Manna (1997) report on a negative dependence between salinity and the activity of dehydrogenases $(r=-0.767)$. Dehydrogenase is an intracellular
Table 3 Coefficients and degrees of soil contamination

\begin{tabular}{|c|c|c|c|c|c|c|c|c|c|c|c|}
\hline \multirow[t]{2}{*}{ Sites } & \multicolumn{5}{|l|}{$\mathrm{CF}$} & \multirow[t]{2}{*}{ Cdeg } & \multicolumn{5}{|c|}{$\mathrm{CF}$ in $\mathrm{Cdeg}(\%)$} \\
\hline & $\mathrm{Zn}$ & $\mathrm{Cu}$ & $\mathrm{Ni}$ & $\mathrm{Pb}$ & $\mathrm{Cd}$ & & $\mathrm{Zn}$ & $\mathrm{Cu}$ & $\mathrm{Ni}$ & $\mathrm{Pb}$ & $\mathrm{Cd}$ \\
\hline 1 & 1.22 & 1.87 & 0.19 & 4.45 & 2.69 & 10.4 & 11.7 & 18.0 & 1.23 & 42.7 & 25.8 \\
\hline 2 & 1.72 & 1.92 & 0.19 & 4.53 & 0 & 8.36 & 20.6 & 23.0 & 2.27 & 54.2 & 0 \\
\hline 3 & 1.31 & 2.36 & 0.32 & 7.35 & 0 & 11.3 & 11.6 & 20.9 & 2.83 & 65.0 & 0 \\
\hline 4 & 1.68 & 2.40 & 0.55 & 12.6 & 0 & 17.2 & 9.76 & 15.7 & 3.19 & 73.1 & 0 \\
\hline 5 & 4.62 & 7.30 & 3.27 & 74.7 & 1.25 & 91.2 & 5.07 & 8.00 & 3.59 & 59.5 & 1.37 \\
\hline 6 & 4.29 & 5.84 & 2.37 & 54.3 & 3.18 & 70.0 & 6.13 & 8.35 & 3.39 & 77.6 & 4.55 \\
\hline 7 & 4.06 & 7.32 & 3.23 & 74.0 & 1.25 & 89.9 & 4.52 & 8.15 & 3.59 & 82.4 & 1.39 \\
\hline 8 & 4.95 & 56.3 & 0.59 & 13.6 & 9.61 & 85.1 & 5.81 & 66.2 & 0.69 & 16.0 & 11.3 \\
\hline 9 & 18.1 & 25.6 & 0.17 & 4.05 & 0 & 47.8 & 37.9 & 53.5 & 0.36 & 8.47 & 0 \\
\hline 10 & 22.1 & 18.5 & 0.06 & 1.54 & 3.75 & 46.0 & 48.1 & 40.3 & 0.13 & 3.35 & 8.16 \\
\hline 11 & 5.88 & 4.08 & 2.68 & 61.4 & 2.30 & 76.3 & 7.71 & 5.35 & 3.21 & 80.4 & 3.01 \\
\hline 12 & 12.1 & 6.72 & 0.16 & 3.74 & 26.8 & 49.6 & 24.5 & 13.6 & 0.32 & 7.54 & 54.1 \\
\hline 13 & 7.58 & 108 & 2.02 & 46.3 & 7.11 & 171 & 4.43 & 63.2 & 1.18 & 27.1 & 4.16 \\
\hline 14 & 14.1 & 14.9 & 0.10 & 2.38 & 6.83 & 38.4 & 36.9 & 38.9 & 0.26 & 6.20 & 17.8 \\
\hline 15 & 4.33 & 19.0 & 2.89 & 66.2 & 6.92 & 99.4 & 4.36 & 19.2 & 2.91 & 66.6 & 6.96 \\
\hline 16 & 14.5 & 20.6 & 0.17 & 4.05 & 7.21 & 47.0 & 30.8 & 43.9 & 0.36 & 8.63 & 15.4 \\
\hline
\end{tabular}

$C F$ contamination factor, $C F$ in $C_{d e g}$ degree of contamination 
Fig. 3 Value samples BIF (sites from 1 to 16 )

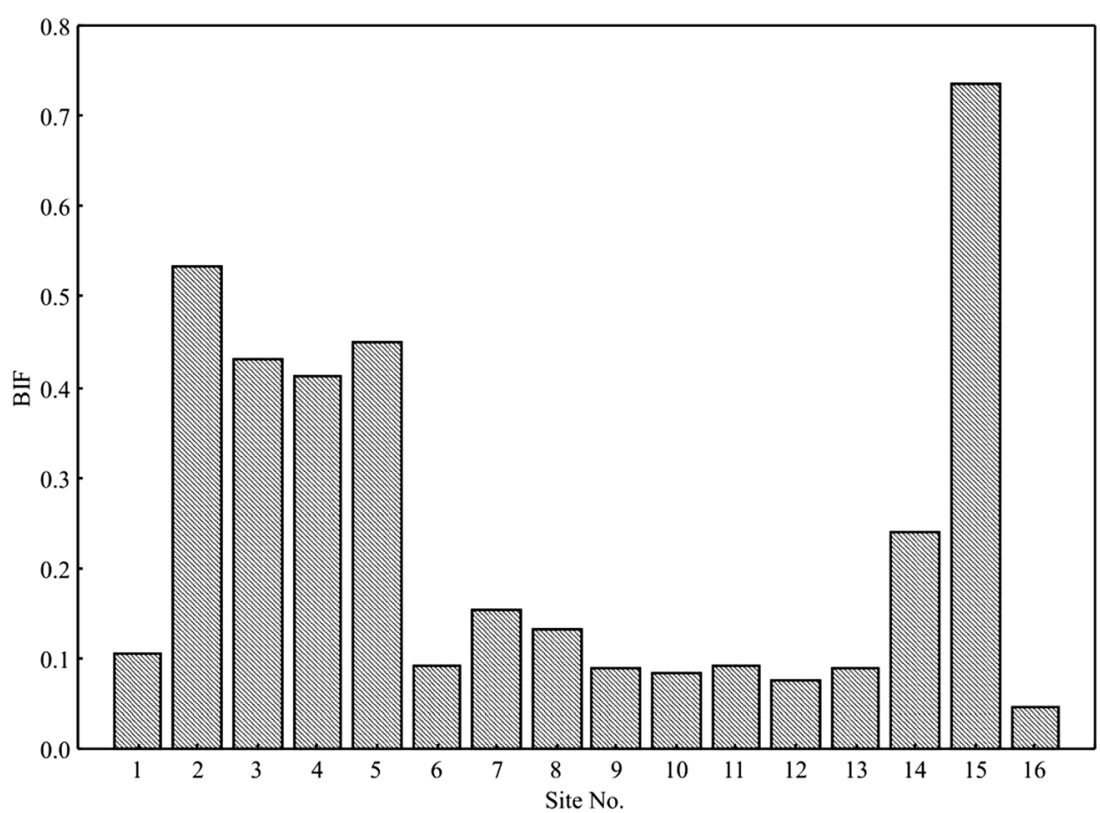

enzyme, considered an indicator of the viable microbial activity in soils. The influence of soil EC on enzyme activities might involve the level of soil salt affecting enzyme configuration and formation of its activity center. The process of protein salting out occurs and so enzymes lose its biological activity. Similar results are reported by Siddikee et al. (2011) who studied the influence of varying degree of salinity-sodicity stress on enzyme (dehydrogenases, cellulase, glucosidase, protease, alkaline, and acid phosphatase) of coastal soils of the Yellow Sea, South Korea. The enzyme activity associated with salinization varied depending on the degree of salinization, as well as on the type of enzyme (Pan et al. 2013). There was recorded no negative dependence between the activity of catalase and $\mathrm{pH}, \mathrm{EC}_{1: 5}$, whereas Shi et al. (2008) report on soil catalase activity being closely related to soil EC and no significant relationship with other physicochemical properties.
Catalase can split hydrogen peroxide into molecular oxygen and water and thus prevent cells from damage by reactive oxygen species. According to Jaspers and Kangasjärvi (2010) and $\mathrm{Wu}$ et al. (2012), catalase is an anti-oxidation enzyme, participating in the defense of the plants from abiotic and biotic factors triggering oxidation stress among plants, e.g., growing in saline soils. Catalase is active over a wide $\mathrm{pH}$ range and its activity does not drop until $\mathrm{pH}$ is below 3.5. In the samples under study, $\mathrm{pH}$ was high and ranged from 5.4 to 7.7 in $\mathrm{H}_{2} \mathrm{O}$ and 3.9 to 7.8 in $1 \mathrm{M} \mathrm{KCl}$. According to Wilding (1985) classification, the CV values of soil dehydrogenase activities $(91 \%)$ and catalase activity $(106 \%)$ were high.

The value of BIF (Stefanic et al. 1984) calculated based on the activity of dehydrogenases and catalase was highest (BIF 0.735 ) in the soil sampled from the arable field (site 15)
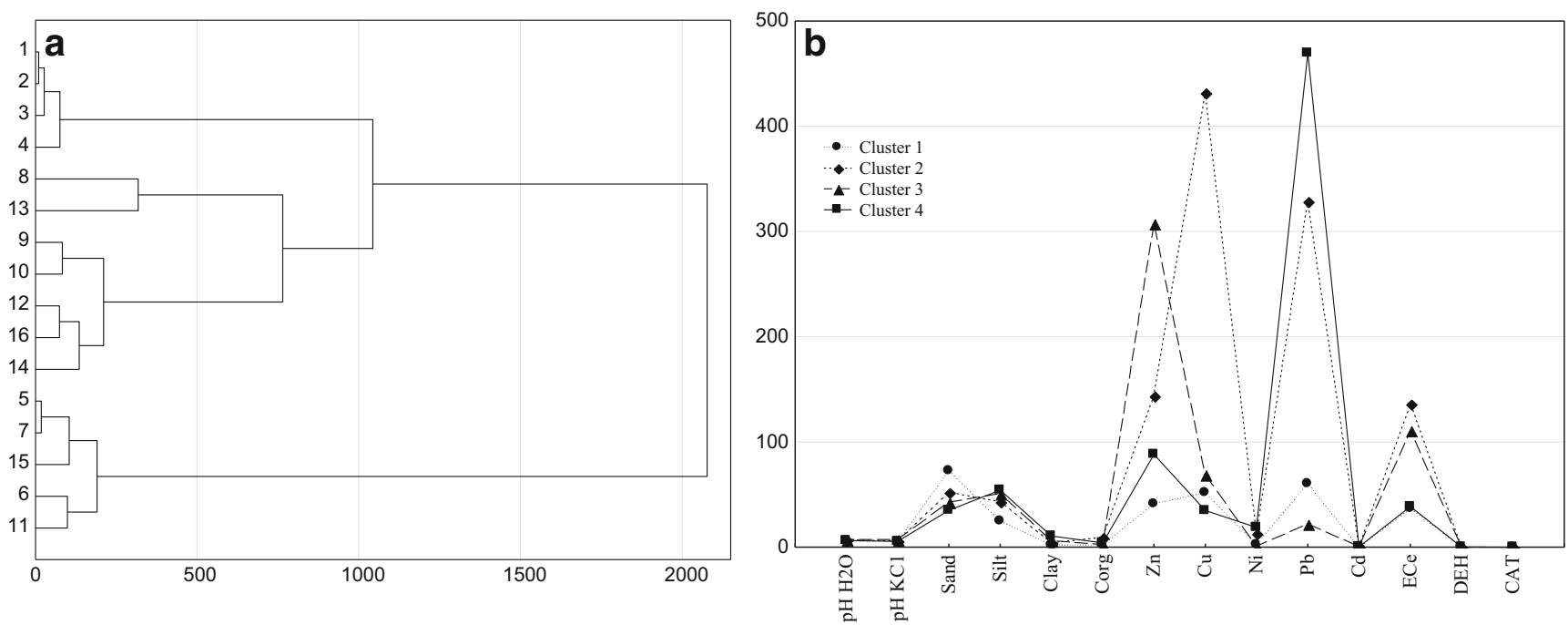

Fig. 4 Similarity dendrogram for sampling sites (1-16) (a) and a graph $k$ - means for the study properties (b) 
Fig. 5 Configuration of variables in the system of the first two axes $\mathrm{PC} 1$ and $\mathrm{PC} 2$ of principal components

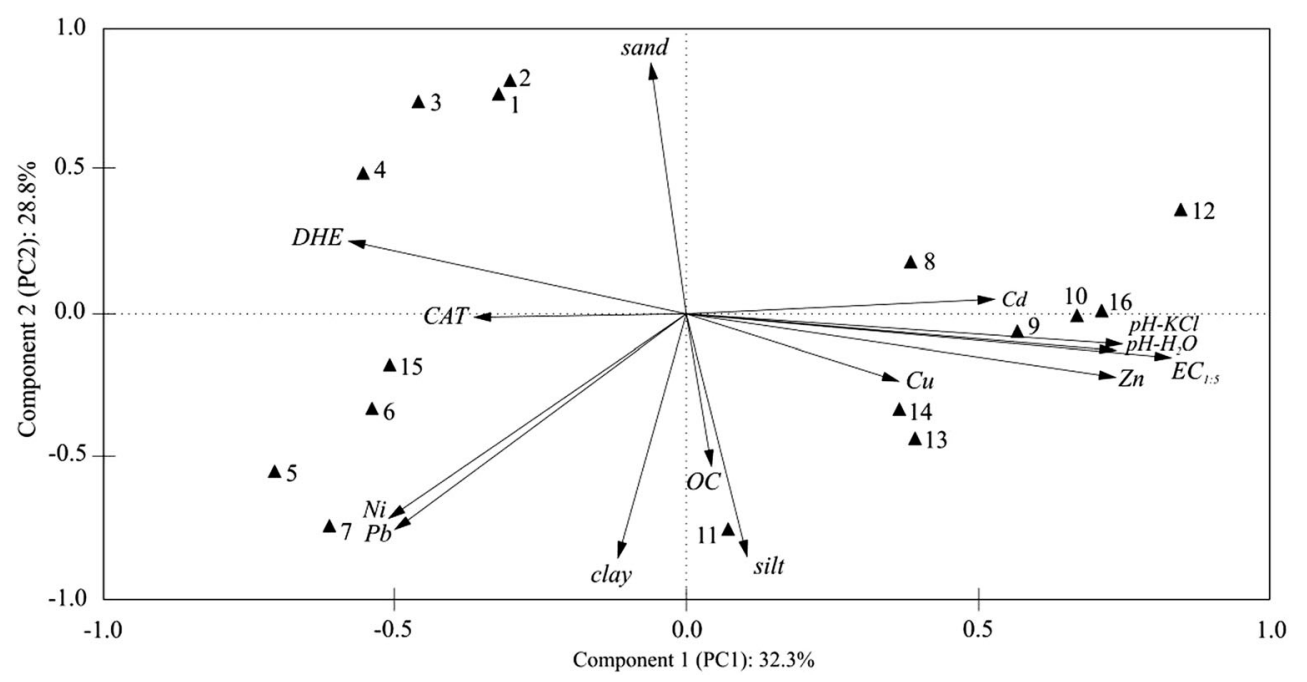

(Fig. 3). In the soil sampled from the sites with the highest salinity $\left(\mathrm{EC}_{1: 5}\right)$, the value of the biochemical fertility index was lowest $(\mathrm{BIF}<0.1)$ (sites 6, 9, 10, 11, 12, 13). A similar dependence was earlier reported by Telesiński (2012), while Saviozzi et al. (2011) report on BIF values not being considerably different from the control sample and the sample under study, indicating that such an index is unable to determine effects of salt on the biological activity of soil.

Cluster analysis was used to identify the similarity of the groups between the samples from points grouping all 16 sampling sites into four significant clusters (Fig. 4a). Based on the data clustering with Ward's method (1963), it was found that cluster 2 includes two soil samples (samples 8 and 13). Those sampling sites showed a higher copper content. Five soil samples $(9,10,12,14$, and 16) were included in cluster 3 (Fig. 4a) due to a high zinc content and electrical conductivity $\left(\mathrm{EC}_{1: 5}\right)$ (Fig. 4b). Five soil samples $(5,6,7,11$, and 15) fell within

Table 4 Relationship between selected soil properties $(n=16$; $P<0.05)$

\begin{tabular}{|c|c|c|c|}
\hline \multicolumn{2}{|l|}{ Variables } & \multirow[t]{2}{*}{ Equation } & \multirow[t]{2}{*}{$r$} \\
\hline Dependent & Independent & & \\
\hline Total copper & Organic carbon & $y=42.6643+35.987 x$ & 0.688 \\
\hline Total nickel & Organic carbon & $\mathrm{y}=0.10634+2.0257 \mathrm{x}$ & 0.510 \\
\hline Total lead & Organic carbon & $y=26.5859+50.6427 x$ & 0.510 \\
\hline Total zinc & $\mathrm{EC}_{1: 5}$ & $y=36.6079+1.6333 x$ & 0.668 \\
\hline Total copper & $\mathrm{EC}_{1: 5}$ & $\mathrm{y}=1.8252+1.1061 \mathrm{x}$ & 0.509 \\
\hline Dehydrogenases & $\mathrm{EC}_{1: 5}$ & $\mathrm{y}=0.4866-0.0032 \mathrm{x}$ & -0.665 \\
\hline Total nickel & Clay & $y=-0.6293+1.3467 x$ & 0.678 \\
\hline Total lead & Clay & $y=-15.7324+33.6666 x$ & 0.678 \\
\hline Total zinc & $\mathrm{pH} \mathrm{KCl}$ & $y=-214.9774+58.1292 x$ & 0.664 \\
\hline Total cadmium & $\mathrm{pH} \mathrm{KCl}$ & $y=-1.2889+0.3112 x$ & 0.510 \\
\hline $\mathrm{EC}_{1: 5}$ & $\mathrm{pH} \mathrm{H} \mathrm{H}_{2} \mathrm{O}$ & $y=-19.53+3.8975 x$ & 0.736 \\
\hline $\mathrm{EC}_{1: 5}$ & $\mathrm{pH} \mathrm{KCl}$ & $\mathrm{y}=-8.9739+2.5226 \mathrm{x}$ & 0.705 \\
\hline
\end{tabular}

cluster 4 due to a high lead content and low $\mathrm{EC}_{1: 5}$, the content of copper and sand. It is seen from the dendrogram that cluster 4 is characterized by the biggest Euclidean distance to the other clusters (high significance of clustering).

Table 5 displays the factor loadings, as well as the eigenvalues. Two principal components (PC1 and PC2) were extracted from the available data set that explained a total variance of approximately $61.02 \%$. Factor 1 (PC1) is responsible for $32.26 \%$ of the total element variables and indicated a high correlation with $\mathrm{pH}$ in $\mathrm{H}_{2} \mathrm{O}(0.807)$ and $\mathrm{KCl}(0.818)$, the content of zinc (0.806), and $\mathrm{EC}_{1: 5}(0.910)$. Factor 2 (PC2) is dominated by sand (0.909), silt (0.880), and clay $(-0.885)$ and the contents of nickel $(-0.740)$ and lead $(-0.740)$. These two heavy

Table 5 Values of the two extracted factor loadings for 14 elements

\begin{tabular}{ccc}
\hline \multirow{2}{*}{ Parameters } & \multicolumn{2}{l}{ Component matrix } \\
\cline { 2 - 3 } & PC1 & PC2 \\
\hline $\mathrm{pH} \mathrm{H}_{2} \mathrm{O}$ & $0.807^{*}$ & -0.131 \\
$\mathrm{pH} \mathrm{KCl}$ & $0.818^{*}$ & -0.108 \\
$\mathrm{Sand}$ & -0.066 & $0.909^{*}$ \\
$\mathrm{Silt}$ & 0.114 & $-0.880^{*}$ \\
$\mathrm{Clay}$ & -0.128 & $-0.885^{*}$ \\
$\mathrm{OC}$ & 0.047 & -0.553 \\
$\mathrm{Zn}$ & $0.806^{*}$ & -0.229 \\
$\mathrm{Cu}$ & 0.399 & -0.243 \\
$\mathrm{Ni}$ & -0.558 & $-0.740^{*}$ \\
$\mathrm{~Pb}$ & -0.558 & $-0.740^{*}$ \\
$\mathrm{Cd}$ & 0.578 & 0.053 \\
$\mathrm{EC}{ }_{1: 5} \mathrm{DEH}$ & $0.910^{*}$ & -0.158 \\
$\mathrm{CAT}$ & -0.634 & 0.264 \\
& -0.398 & -0.012 \\
Variation $(\%)$ & 32.26 & 28.76 \\
Eigenvalue & 4.516 & 4.026 \\
\hline
\end{tabular}

*Statistically significant 
metals may reflect the anthropogenic contamination in saline soil grasslands. The activity of dehydrogenases and catalase was negatively correlated with sites $8,9,10,12,13$, and 16 (sites along the drainage ditch). The results of the analysis show that soil $\mathrm{EC}_{1: 5}, \mathrm{pH}$, and the content of zinc had a negative effect on the activity of soil enzymes, as indicated by the vectors along the axes of the coordinate system. Figure 5 shows correlations between the content of zinc and copper. Sampling sites 8, 9, 10, 12, 13 , and 16 are located closer to the vectors of those variables, which proves that the soil at those sites is contaminated with $\mathrm{Zn}$ and $\mathrm{Cu}$ originated from corroded brine pipes.

\section{Proposal for land management}

According to the results, most of the soils showed strong sorption properties of the clay fraction and organic matter (Tables 1 and 4). However, the properties of soils located along the ditch (samples 8-16) can significantly favor the limited mobility of heavy metals in alkaline environment (Brümmer and Herms 1983; Kabata-Pendias and Pendias 2001). However, some studies revealed that salinity can increase metal mobility (e.g., Hatje et al. 2003; Acosta et al. 2011). This is caused by both the complexation of salt anions with heavy metals and the competition between salt cations with heavy metal ions for sorption sites at the solid phase.

Taking into account the protective status of the area, it is difficult to show definitely a solution for land management. As mentioned earlier, in the near future, the revitalization of that reserve is planned; it is to facilitate the succession of halophytes beyond the zone around the ditch. With that in mind, according to the authors, one shall focus on a possibility of using native halophyte species for phytoremediation. As tolerant and resistant to an excess of toxic ions, mainly sodium and chloride, these plants may also be able to accumulate heavy metals (Manousaki and Kalogerakis 2011; Lutts and Lefevre 2015).These elements are mainly accumulated in the root, with some quantities translocated to the stems and leaves, especially in Salicornia europaea and Aster tripolium - halophytes commonly occurred in the study area (Lüttge 1975; Milić et al. 2012). As such, the plants would be ideal for phytostabilization rather than phytoextraction, which, however, requires more detailed research.

\section{Conclusions}

The obtained results clearly demonstrated that due to the longterm human impact, the studied salt-affected soils were contaminated by heavy metals. Under the Regulation of the Minister of Environment of 9 September 2002 on standards for soil quality and land quality standards (Journal of Laws No 165, item 1359, 2002), it was found that the admissible contents of $\mathrm{Zn}, \mathrm{Cu}, \mathrm{Pb}$, and $\mathrm{Cd}$ were exceeded in the study area. Based on the PCA analysis and $\mathrm{EF}$ index, it was revealed that $\mathrm{Zn}, \mathrm{Cu}, \mathrm{Pb}, \mathrm{Cd}$, and $\mathrm{Ni}$ were controlled by various anthropogenic activities (agricultural and human activities, vehicular emissions, etc.). The analysis of correlation confirmed the effect of a high salinity level, content of organic carbon, and the clay fraction on the content of heavy metals in soils. The BIF values facilitate monitoring the effects of salts on selected biological activity of soils. Effects of salinization on soil enzymes in the grassland habitat Natura 2000 in Ciechocinek (Poland) must be further investigated to provide rational management measures to promote long-term sustainability. A lack of inhibition of the enzymes as affected by heavy metals could have been due to the content of organic matter and clay fraction which bind enzymatic protein, protecting it from negative environmental factors. It is also known that heavy metals at little concentrations are activators of many enzymes. Bearing in mind the revitalization of the research area planned, one could also consider the applicability of some native halophytes to phytoremediation.

Acknowledgements The authors would like to thank the Faculty of Agriculture and Biotechnology, UTP University of Science and Technology in Bydgoszcz for their support for this research work.

Open Access This article is distributed under the terms of the Creative Commons Attribution 4.0 International License (http:// creativecommons.org/licenses/by/4.0/), which permits unrestricted use, distribution, and reproduction in any medium, provided you give appropriate credit to the original author(s) and the source, provide a link to the Creative Commons license, and indicate if changes were made.

\section{References}

Abrol IP, Yadav JSP, Massoud FI (1988) Salt-affected soils and their management. FAO Soils Bulletin, 39, Rome

Acosta JA, Jansen B, Kalbitz K, Faz A, Martınez-Martınez S (2011) Salinity increases mobility of heavy metals in soils. Chemosphere $85: 1318-1324$

Alef K (1995) Dehydrogenase activity. In: Methods in Applied Soil Microbiology and Biochemistry (Eds K.Alef, P. Nannipieri). London, Academic Press, 228-231

Alef K, Nannipieri P (1995) Catalase activity. In: Methods in Applied Soil Microbiology and Biochemistry(Eds K. Alef, P. Nannipieri). London, Academic Press, 362-363

Ali SM, Malik RN (2011) Spatial distribution of metals in top soils of Islamabad City, Pakistan. Environ Monit Assess 172:1-16. https:// doi.org/10.1007/s10661-010-1314-x

Ashworth DJ, Alloway BJ (2008) Influence of dissolved organic matter on the solubility of heavy metals in sewage-sludge-amended soils. Commun Soil Sci Plant Analysis 39:538-550. https://doi.org/10. 1080/00103620701826787

Atiemo MS, Ofosu GF, Mensah HK, Tutu AO, Linda Palm NDM, Blankson SA (2011) Contamination assessment of heavy metals in road dust from selected roads in Accra, Ghana. Res J Environ Earth Sci 3(5):473-480

Bambara LT, Kabore K, Cisse O, Derra M, Zougmoré F, Bentil N (2015) Assessment of pollution in agricultural soil and interrelationship between the heavy metals at Paspanga, Burkina Faso. J Environ Sci Toxicol Food Technol 9(8):2319-2399 
Bartkowiak A, Lemanowicz J (2014) Application of biochemical tests to evaluate the pollution of the Unislaw Basin soils with heavy metals. Inter J Environ Res 8(1):93-100

Batra L, Manna M (1997) Dehydrogenase activity and microbial biomass carbon in salt-affected soils of semiarid and arid regions. Arid Soil Res Rehab 11(3):295-303. https://doi.org/10.1080/15324989709381481

Bednarek R, Dziadowiec H, Pokojska U, Prusinkiewicz Z (2004) Ecopedological studies. PWN, Warsaw (in Polish)

Bielińska EJ, Gruszecki T (2010) Influence of secondary plant succession on the enzymatic activity of soil in selected Natura 2000 natural habitats. Soil Sci Annual 61(4):7-14

Brümmer G, Herms U (1983) Influence of soil reaction and organic matter on the solubility of heavy metals in soils. In: Ulrich B. (ed.) Effects of accumulation of air pollutants in forest ecosystems. Pankrath J.D. Reidel Publishing Company. Dordrecht, 233-243

Crock JG, Severson R (1980) Four reference soil and rock samples for measuring element availability in the western energy regions. Geochem Survey Circular 841:1-16

Czajka K, Sziwa D, Drobnik M, Latour T (2006) The comparison of the microclimate and aerosols properties in the salt mines and the artificial salt chambers. Balneologia Polska 3:176-181 (in Polish with English abstract)

Czarnowska K (1996) Total content of heavy metals in parent rocks as reference background levels of soil. Soil Sci Annual Suppl 47:43-50

Dube A, Zbytniewski R, Kowalkowski T, Cukrowska E, Buszewski B (2001) Adsorption and migration of heavy metals in soil. Pol J Environ Stud 10(1):1-10

Elik A (2003) Heavy metal accumulation in street dust samples in Sivas. Commun Soil Sci Plant Analysis 34(1-2):145-156. https://doi.org/ 10.1081/CSS-120017422

Govil PK, Sorlie JE, Murthy NN, Sujatha D, Reddy GLN, Rudolph-Lund K, Krishna AK, Ram Mohan K (2008) Soil contamination of heavy metals in the Katedan industrial development area, Hyderabad, India. Environ Monit Assess 140:313-323. https://doi.org/10. 1007/s10661-007-9869-x

Gugnacka-Fiedor W (2011) Taxonomic diversity of mosses in the area of graduation towers in the town of Ciechocinek. Ecol Quest 14:31-33. https://doi.org/10.2478/v10090-011-0010-y

Hu Y, Liu X, Bai J, Shih K, Zeng EY, Cheng H (2013) Assessing heavy metal pollution in the surface soils of a region that had undergone three decades of intense industrialization and urbanization. Environ Sci Pollut Res 20:6150-6159. https://doi.org/10.1007/s11356-0131668-Z

Hulisz P, Charzyński P, Giani L (2010) Application of the WRB classification to salt-affected soils in Poland and Germany. Pol J Soil Sci 43(1):81-92

Hulisz P, Piernik A, Mantilla-Contreras J, Elvisto T (2016) Main driving factors for seacoast vegetation in the Southern and Eastern Baltic. Wetlands. https://doi.org/10.1007/s13157-016-0803-2

Håkanson L (1980) An ecological risk index for aquatic pollution control: a sedimentological approach. Water Res 14:975-1001

Hatje V, Payne TE, Hill DM, McOrist G, Birch GF, Szymczak R (2003) Kinetics of trace element uptake and release by particles in estuarine waters: effects of pH, salinity, and particle loading. Environ Inter 29: 619-629

IUSS Working Group WRB (2015) World Reference Base for Soil Resources 2014, update 2015 International soil classification system for naming soils and creating legends for soil maps. World Soil Resources Reports No. 106. FAO, Rome

Jackson ML (1958) Soil chemical analysis. Constable Ltd, London

Jankowska-Huflejt H (2006) The function of permanent grasslands resources protection. J Water Land Dev 10:55-65

Johnson JI, Temple KL (1964) Some variables affecting the measurements of catalase activity in soil. Soil Sci Soc Am J 28:207-216. https://doi.org/10.2136/sssaj1964.03615995002800020024x
Jaspers P, Kangasjärvi J (2010) Reactive oxygen species in abiotic stress signaling. Physiol Plant 138:405-413. https://doi.org/10.1111/j. 1399-3054.2009.01321.x

Journal of Laws No 165, item 1359 (2002) Regulation of the Minister of Environment dated 9 September 2002 on standards for soil quality and land quality standards (in Polish)

Journal of Laws, item 1031 (2012) Regulation of the Ministry of Environment dated 24 August 2012 concerning evaluation of substances levels in the air (in Polish)

Journal of Laws, item 1395 (2016) Regulation of the Ministry of Environment dated 1 September 2016 on assessment procedures for the land surface pollution (in Polish)

Kabata-Pendias A, Pendias H (2001) Trace elements in soils and plants, 3rd edn. Press, CRC, 397p

Kennou B, El Meray M, Romane A, Arjouni Y (2015) Assessment of heavy metal availability $(\mathrm{Pb}, \mathrm{Cu}, \mathrm{Cr}, \mathrm{Cd}, \mathrm{Zn})$ and speciation in contaminated soils and sediment of discharge by sequential extraction. Environ Earth Sci 74:5849-5858. https://doi.org/10.1007/ s12665-015-4609-y

Kopeć D, Woziwoda B, Forysiak J, Sławik Ł, Ptak A, Charążka E (2016) The use of ALS, botanical, and soil data to monitor the environmental hazards and regeneration capacity of areas devastated by highway construction. Environ Sci Pollut Res 23(14):13718-13731. https://doi.org/10.1007/s11356-015-5637-6

Krishna AK, Govil PK (2007) Soil contamination due to heavy metals from an industrial area of Surat, Gujarat, Western India. Environ Monit Assess 124(1-3):263-275. https://doi.org/10.1007/s10661006-9224-7

Lee SH, Lee JS, Choi YJ, Kim JG (2009) In situ stabilization of cadmium, lead-, and zinc-contaminated soil using various amendments. Chemosphere 77:1069-1075. https://doi.org/10.1016/j. chemosphere.2009.08.056

Lemanowicz J, Bartkowiak A (2013) Diagnosis of the content of selected heavy metals in the soils of the Pałuki region against their enzymatic activity. Arch Environ Protec 39(3):23-32. https://doi.org/10.2478/ aep-2013-0026

Lemanowicz J, Krzyżaniak M (2015) Vertical distribution of phosphorus concentrations, phosphatase activity and further soil chemical properties in salt-affected Mollic Gleysols in Poland. Environ Earth Sci 74:2719-2728. https://doi.org/10.1007/s12665-015-4294-x

Li X, Lee SI, Wong SC, Shi W, Thornton I (2004) The study of metal contamination in urban soils of Hong Kong using a GIS-based approach. Environ Pollut 129(11):113-124. https://doi.org/10.1016/j. envpol.2003.09.030

Loska K, Wiechuła D (2003) Application of principal component analysis for the estimation of source of heavy metal contamination in surface sediments from the Rybnik Reservoir. Chemosphere 51: 723-733. https://doi.org/10.1016/S0045-6535(03)00187-5

Loska K, Wiechuła D, Korus I (2004) Metal contamination of farming soils affected by industry. Environ Inter 30:159-165. https://doi.org/ 10.1016/S0160-4120(03)00157-0

Lutts S, Lefevre I (2015) How can we take advantage of halophyte properties to cope with heavy metal toxicity in salt-affected areas? Annals Botany 115(3):509-528

Lüttge U (1975) Salt glands. In: Baker DA, Hall JL (eds) Ion transport in plant cells and tissues. North-Holland Publishing Comp, Amsterdam, Oxford, pp 335-376

Macedo-Sousa JA, Soares A, Tarazona JV (2009) A conceptual model for assessing risks in a Mediterranean Natura 2000 Network site. Sci. Total Environ 407:1224-1231

Madrid L, Diaz-Barrientos E, Madrid F (2002) Distribution of heavy metal contents of urban soils in parks of Seville. Chemosphere 49(10): 1301-1308. https://doi.org/10.1016/S0045-6535(02)00530-1

Madrid L, Diaz-Barrientos E, Ruiz-Cortés E, Reinoso R, Biasioli M, Davidson CM, Duarte AC, Grčman H, Hossack I, Hursthouse AS, Kralj T, Ljung K, Otabbong E, Rodrigues S, Urqhart GJ, Ajmone- 
Marsan F (2006) Variability in concentrations of potentially toxic elements in urban parks from six European cities. J Environ Monit 8: 1158-1165. https://doi.org/10.1039/B607980F

Manousaki E, Kalogerakis N (2011) Halophytes - an emerging trend in phytoremediation. Inter J Phytoremediation 13:959-969

Milić D, Luković J, Ninkov J, Zeremski-Škorić T, Zorać L, Vasin J, Milić S (2012) Heavy metal content in halophytic plants from inland and maritime saline areas. Central Europ J Bio 17:307-317

Norvell WA, Wu J, Hopkins DG, Welch RM (2000) Association of cadmium in durum wheat grain with soil chloride and chelate-extractable soil cadmium. Soil Sci Soc Am J 64:2162-2168

Orczewska A, Piotrowska A, Lemanowicz J (2012) Soil acid phosphomonoesterase activity and phosphorus forms in ancient and postagricultural black alder [Alnus Glutonosa (L) Gaertn.] woodland. Acta Soc Bot Pol 81(2):81-86. https://doi.org/10.5586/asbp.2012. 013

Pan C, Liu C, Zhao H, Wang Y (2013) Changes of soil physico-chemical properties and enzyme activities in relation to grassland salinization. Eur J Soil Biol 55:13-19. https://doi.org/10.1016/j.ejsobi.2012.09.009

Paz-Ferreiro J, Lu H, Fu S, Méndez A, Gascó G (2014) Use of phytoremediation and biochar to remediate heavy metal polluted soils: a review. Solid Earth 5:65-75. https://doi.org/10.5194/se-565-2014

Piernik A, Hulisz P, Rokicka A (2015) Micropattern of halophytic vegetation on technogenic soils affected by the soda industry. Soil Sci Plant Nutr 61(Suppl.1):98-112

PN-ISO 10390 1997.Chemical and Agricultural Analysis - Determining soil pH. Polish Standards Committee. Warsaw

Pröbstl U (2003) NATURA 2000 - the influence of the European directives on the development of nature-based sport and outdoor recreation in mountain areas. J Nat Conserv 11:340-345

Ramachandra TV, Shwetmala K (2009) Emission from India's transport sector: state wise synthesis. Atmos Environ 43:5510-5517. https:// doi.org/10.1016/j.atmosenv.2009.07.015

Reeuwijk van LP (2002) Procedures for soil analysis, 6th edn. Wageningen, ISRIC. FAO

Rengasamy P (2006) Soil salinity and sodicity. In: Growing crops with reclaimed wastewater. Inkata press, Melbourne, pp 125-138

Roy M, Mc Donald LM (2015) Metal uptake in plants and health risk assessments in metal-contaminated smelter soils. Land Degrad Dev 26(8):785-792. https://doi.org/10.1002/ldr.2237

Salazar MJ, Pignata ML (2014) Lead accumulation in plants grown in polluted soils. Screening of native species for phytoremediation. J Geochem Explor 137:29-36. https://doi.org/10.1016/j.gexplo.2013. 11.003

Saviozzi A, Cardelli R, Di Puccio R (2011) Impact of salinity on soil biological activities: a laboratory experiment. Commun Soil Sci Plant Anal 42:358-367. https://doi.org/10.1080/00103624.2011. 542226

Schröder W, Roland Pesch R, Zechmeister H, Kratz W, Holy M, Harmens H, Fagerli H, Ilyin I (2010) Atmosphärische Deposition und Anreicherung von Schwermetallen und Stickstoff in Natura-2000Gebieten Deutschlands. Umweltwiss Schadst Forsch 22:711-720

Siddikee MA, Tipayno SC, Kim K, Chung J, Sa T (2011) Influence of varying of salinity-sodicity stress on enzyme activities and bacterial population of coastal soils of Yellow Sea, South Korea. J Micro Biotech 21(4):341-346

Shakeri A, Moore F, Modabberi S (2009) Heavy metal contamination and distribution in the Shiraz industrial complex zone soil, South Shiraz, Iran. World Appl Sci J 6(3):413-425

Shi ZJ, Lu Y, Xu ZG, Fu SL (2008) Enzyme activities of urban soils under different land use in the Shenzhen city, China. Plant Soil Environ 54: 341-346

Siwik-Ziomek A, Lemanowicz J (2014) The content of carbon, nitrogen, phosphorus and sulphur in soil against the activity of selected hydrolases as affected by crop rotation and fertilization. Zemdirbyste-Agriculture 101(4):367-372. 10.13080/z-a.2014.101. 046

Skordas E, Kelepertzis E, Kosmidis D, Panagiotaki P, Vafidis D (2015) Assessment of nutrients and heavy metals in the surface sediments of the artificially lake water reservoir Karla, Thessaly, Greece. Environ Earth Sci 73(8):4483-4493. https://doi.org/10.1007/ s12665-014-3736-1

Stefanic G, Eliade G, Chirogeanu I (1984) Researches concerning a biological index of soil fertility. Proc. $5^{\text {th }}$ Symp. on Soil Biology, Roman. National Soc Soil Sci: $35-45$

Su C, Jiang LQ, Zhang WJ (2014) A review on heavy metal contamination in the soil worldwide: situation, impact and remediation techniques. Environ Skeptics Critics 3(2):24-38

Sutherland RA (2000) Bed sediment associated trace metals in an urban stream. Oaho. Hawaii. Environ Geol 39:611-627

Telesiński A (2012) The effect of salinity on some biochemical indices of soil fertility. Water Environ Rural Areas 12(37):209-217

Thorpe A, Harrison RM (2008) Sources and properties of non-exhaust particulate matter from road traffic: a review. SciTotEnviron $400(1-$ 3):270-282. https://doi.org/10.1016/j.scitotenv.2008.06.007

Thalmann A (1968) Zur methodic derestimung der Dehydrogenaseaktivitäti Boden mittelsTriphenyltetrazoliumchlorid (TTC). Landwirtsch Forschung 21:249-258

Tsiafouli MA, Apostolopoulou E, Mazaris AD, Kallimanis AS, Drakou EG (2013) Human activities in Natura 2000 sites: a highly diversified conservation network. Environ Manag 51:1025-1033

USDA (2006) Keys to soil taxonomy. Tenth Edition. United States Department of Agriculture, Natural Resources Conservation Service, $1-332$

Usman ARA, Kuzyakov Y, Stahr K (2005) Effect of immobilizing substances and salinity on heavy metals availability to wheat grown on sewage sludge-contaminated soil. Soil Sediment Contam 14:329344

Uzarowicz $Ł$ (2011) Technogenic soils developed on mine soils containing iron sulfides in select abandoned industrial sites: environmental hazards and reclamation possibilities. Pol J Environ Stud 20:771782

Ward JH (1963) Hierarchical grouping to optimize an objective function. J Am Statist Assoc 58:236-244

Warot L, Nienartowicz A (2001) The dynamics of the plant communities in the reserve of halophytes "Ciechocinek". In: A. Nienartowicz, M. Kunz (eds.) GIS and Remote Sensing in Studies of Landscape Structure and Functioning, OficynaWyd. "Tupress", Toruń: 231240. (in Polish with English abstract)

Weggler K, McLaughlin MJ, Graham RD (2004) Effect of chloride in soil solution on the plant availability of biosolid-borne cadmium. J Environ Qual 33:496-504

Weng L, Temminghof EJM, Lofts S, Tipping E, van Riemsdijk WH (2002) Complexation with dissolved organic matter and solubility control of heavy metals in a sandy soil. Environ Sci Technol 36: 4804-4810

Wilding LP (1985) Spatial variability: its documentation, accommodation and implication to soil surveys. In: Nielsen DR, Bouma J (eds) Soil spatial variability. Pudoc., Wageningen, pp 166-194

Wilkoń-Michalska J (1962) Halophyte reserve in Ciechocinek and its significance. Chrońmy Przyrodę Ojczystą 18:6-17 (in Polish with English abstract)

Wilkon-Michalska J (1970) Plant succession in the halophyte reserve Ciechocinek between 1954 and 1965. OchronaPrzyrody 35:25-51 (in Polish with English abstract)

Wu GQ, Zhang LN, Wang YY (2012) Response of growth and antioxidant enzymes to osmotic stress in two different wheat (Triticum aestivum L.) cultivars seedlings. Plant Soil Environ 58:534-539 
Wyszkowska J, Borowik A, Kucharski J, Baćmaga M, Tomkiel M, Boros-Lajszner E (2013) The effect of organic fertilizers on the biochemical properties of soil contaminated with zinc. Plant Soil Environ 59(11):500-504

Vacca A, Bianco MR, Murolo M, Violante P (2012) Heavy metals in contaminated soils of the Rio Sitzerri floodplain (Sardinia,
Italy): characterization and impact on pedodiversity. Land Degrad Dev 23(4):250-364. https://doi.org/10.1002/ldr.2153

Zonta R, Zaggia L, Argrse E (1994) Heavy metal and grain size distributions in estuarine shallow water sediments of the Cona Marsh (Venice Lagoon. Italy). Sci Tot Environ 151: $19-28$ 